\title{
Innovation Accelerates Competitiveness and Business Development (SME Entrepreneurs South Tangerang City)
}

\author{
Sonny Indrajaya ${ }^{1}$, Asep Ferry Bastian ${ }^{2}$ \\ Management Program Study, Mercu Buana University, Jakarta, Indonesia ${ }^{1}$, Management \\ Program Study, Syekh-Yusuf Islam University, Tangerang, Indonesia ${ }^{2}$ \\ sonny.indrajaya@mercubuana.ac.id ${ }^{1}$, a.ferry.bastian@unis.ac.id ${ }^{2}$
}

\begin{abstract}
Small and Medium Entrepreneurs in South Tangerang City who are still relatively new to start up businesses will continue to look for information about market opportunities and product development, but are not yet too developed and still in need of digital technology that will create innovations for products that will be liked by buyers. Innovation will certainly also provide small and medium entrepreneurs to be able to compete and develop their business. This research uses quantitative methods and will analyze 365 respondents who have filled out the questionnaire. This analysis uses WRAP PLS (Partial Least Square). The results obtained for the relationship between the 3 variables have a positive and significant effect. JEL classification: M2, M3, M21, M31
\end{abstract}

Keywords : Innovation; Business competition; Business Development

\section{Introduction}

The digital era as a term used in the emergence of digital technology, internet networks, especially information technology. The business sector in the digital era is experiencing a very fundamental change in business processes due to the emergence of information technology. The process business is a collection of activities that produce something and every process will be triggered by an event (Magal and Word 2012). The business process is a collection of activities to be able to produce products and services that have useful value for related companies that is needed to achieve a final value that is valuable to the company (Kelly R. Rainer 2011).

This was also stated who revealed that information technology has inspired reengineering of various traditional business processes. Oxford English Dictionary (OED) explains the notion of a $\mathrm{n}$ information technology consists of hardware and software which includes networks and telecommunications, this is used in business relationships (Hall and Singleton 2009). ITTA stands for Information Technology Association of America which provides an understanding of information technology: a study, design and implementation, development and support for information system management with a computer-based focus on hardware and software applications for computers.

There are three pressures or factors that cause business change, namely customers, competition, and change. The first pressure comes from customers, where customers now like the easy access to information on goods and services they want. This is in line with changes in customer behavior that is increasingly close to information technology. The second pressure comes from competition between companies. Increasingly sharp business competition makes companies have to do new and innovative things in the face of changes in information technology. The third pressure comes from change (Hammer and Champy 1993). Revealed that 
the market, products, services, business environment and technology will continue to change and develop rapidly. This requires companies to be able to adapt to all forms of change, this is the point of being able to survive and be able to win in the competition. These three pressures are driving business change from traditional systems to digital-based systems. This process of change is better known as digital transformation (Hartono 2005).

Today more and more are becoming entrepreneurs. The business sectors they are involved in are even more diverse. Starting from culinary, fashion, technology, to sociopreneurs, together with the opportunity comes of course there are challenges that must be faced by entrepreneurs, after succeeding in the pioneering stage of the business, of course entrepreneurs need to think to develop their business to the next stage, in addition to capital, digital transformation in the sense of utilizing digital technology and modern work tools can be a solution.

Based on this definition, it can be said that small and medium businesses (SME) are business entities owned by individuals who are not subsidiaries or other branch companies with the criteria of having business capital that has certain restrictions. Lack of information about technology makes small and medium businesses reluctant to turn to digital business to advance business in today's fierce business competition. Founder of Digital Tram and Digital Tram Expert Erwin Panigoro said, there are several things that make it difficult for small and medium businesses to switch to digital: 1 . Resistance to innovation or change. 2 . Some small and medium businesses think technology is new, so they still grope their business potential first. 3 . technology. In the City of South Tangerang, for example, $60 \%$ of 500 small and medium-sized businesses in one community consider their products to not require technology, said Erwin in a data forum event at the Smesco building.

Small and medium entrepreneurs in the city of South Tangerang, who are still relatively new, starting a business, will continue to look for information about market opportunities and product development. The Center for Science and Technology Research (Puspiptek) once offered technology development for small and medium entrepreneurs in the City of South Tangerang. Sri Setiawati, Head of Puspiptek, once said that the development of SME businesses in South Tangerang is still done traditionally, so it has not been able to increase its selling value. The explanation above explains that small and medium entrepreneurs in South Tangerang have not developed rapidly.

\section{Literature Review}

\subsection{Innovation}

Innovation is a transformation of knowledge into new products, processes and services and actions using something new (Sutarno 2012). Divides the company's strategy in developing its innovation into 4: Prospector, Analyzer, Defenders, Reactor (Wawan 2015). Innovation is used for success in the economy by using new ways and new combinations of old ways by converting an input into an output in technology, that produce large or drastic changes in the comparison between the use values perceived by consumers of the benefits of a product (goods and / or services) and prices set by the producer (Avanti Fontana 2011).

\subsection{Business Competition}

Basu (2009) states that business competition is something that is termed and often appears in various references in the aspects of business competition law (Basu 2009). A company rarely 
stands alone in selling to certain customer markets. The company competes with a number of competitors. These competitors must be identified, monitored and avoided to gain and maintain customer loyalty (Thamrin Abdullah 2012). Business competition is a matter of competition between independent business actors with their efforts to get consumers by being offered good quality goods and services at good prices (AkhmadM, 2007).

\subsection{Business Development}

Company growth can be measured by looking at sales growth. This measurement can only see the company's growth from the marketing aspect of the company alone. Another measurement is to look at the company's operating profit growth (Sartono 2011). In the development of a business, it will be the responsibility of entrepreneurs (entrepreneurs) who are required to have foresight, motivation and creativity, if this can be done by every entrepreneur, then there is great hope to be able to make a small business. medium scale business. even become big business (Panji Anoraga 2011). Business development is an effort made by the government, the community, and other stakeholders to empower business through the provision of facilities, mentoring assistance and reinforcement assistance to grow and improve business capability and competitiveness (Mulyadi Nitisusantro 2010).

\section{Hypotheses Development}

\subsection{Innovation and Business Competition}

This study discusses innovations that lead to competitive competition in small and medium businesses. Innovation will be an important strategy to improve, compare, and improve business to achieve better excellence (Anyanitha Distanont and Orapan Khongmalai 2018). This study uses techniques to find answers to questions asked. This research found that innovation in marketing initiatives can be a function of the contribution made to its competitiveness (S. Guptaa, NK. Malhotra, M. Czinkotac and P. Foroudi 2016). The hypothesis is compiled in this study by connecting the innovative business model with the company's competitive advantage, where this assumption has been fully proven from the research results. (Stoilkovska, et.al, 2015). The second hypothesis in this study is Hyphotesis 1 : Effect of innovation on business competition?

\subsection{Business Competition and Business Development}

The result of excellence in competing in a travel agency can be realized if the company tries to maintain good relationships with competitors and learns and implements a competitive strategy in the right business and there is entrepreneurial intention that can offer something relatively new. Service to consumers in order to compete (Chih-Hsing Liu et. al, 2019). Denton is a retail center with a focus on restaurant chains and big box stores, CBD can be shifted from low-end retail to local dining and beverage outlets. For the two different districts it has been seen to increase the unique competitive advantage. The CBD case can be particularly useful for many other cities where the advantages of this network are already over local retailers as well as those involved in business clusters (Murray D. Rice and Joshua P. Bova, 2020). The effect that occurs from undisciplined competition in the product market among company members that has a lower market power than the industry itself. Shows that there is product competition in the 
market, running with a disciplined mechanism with fewer incentives by shareholders as chaebol control holders in order to pursue personal gain (Hee Sub Byun 2018). The third hypothesis in this study is Hyphotesis $2:$ Effect of business competition on Business Development ?

\section{Methods}

\subsection{Research Design}

Using survey methods. The survey was conducted to obtain facts about the symptoms of problems that arise. The survey was conducted by distributing

questionnaires. The study uses quantitative methods to analyze hypotheses and to analyze questionnaires and tabulated using Wrap PLS analysis tools.

\subsection{Questionnaire}

This study will use a closed questionnaire or questions whose answers have been provided by the researcher. Distribution of questionnaires in this study to small and medium entrepreneurs who can answer the questionnaire Measurement of variables using a Likert scale 1-5 consisting of positive and negative statements with 5 categories of answers.

\subsection{Population and Samples}

The population of small and medium-sized entrepreneurs domiciled in the City of South Tangerang, Indonesia as respondents. This study uses proportional sampling in the city of West Jakarta. Data collected will be tabulated and analyzed by 365 respondents.

\section{Results and Discussions}

\subsection{Convergent Validity Test}

Table 1. Combined Loading

\begin{tabular}{|c|c|c|c|c|}
\hline Indicator & $\mathbf{X 1}$ & $\mathrm{X2}$ & Y1 & Y2 \\
\hline \multicolumn{5}{|c|}{ Innovation (X1) } \\
\hline $\mathrm{X} 2.1$ & & 0.804 & & \\
\hline $\mathrm{X} 2.2$ & & 0.844 & & \\
\hline $\mathrm{X} 2.3$ & & 0.825 & & \\
\hline $\mathrm{X} 2.4$ & & 0.843 & & \\
\hline $\mathrm{X} 2.5$ & & 0.745 & & \\
\hline \multicolumn{5}{|c|}{ Business Competition (Y1) } \\
\hline Y1.1 & & & 0.780 & \\
\hline Y1.2 & & & 0.789 & \\
\hline Y1.3 & & & 0.810 & \\
\hline Y1.4 & & & 0.721 & \\
\hline \multicolumn{5}{|c|}{ Business Development (Y2) } \\
\hline Y2.1 & & & & 0.752 \\
\hline
\end{tabular}




\begin{tabular}{rr} 
Y2.2 & 0.744 \\
Y2.3 & 0.795 \\
Y2.4 & 0.742 \\
\hline
\end{tabular}

Table 1 shows each indicator on the variable, has the value of item loading > cross loading, so each indicator can be said discriminant validity is met.

\subsection{Discriminant Validity Test}

Table 2. AVE Root and Correlation Coefficient

\begin{tabular}{lccc}
\hline \multicolumn{1}{c}{ Variabel } & X2 & Y1 & Y2 \\
\hline X1 (Innovation)) & 0.813 & 0.519 & 0.385 \\
Y1 (Business Competition)) & 0.519 & 0.776 & 0.462 \\
$\underline{\text { Y2 (Business Development) }}$ & $\underline{0.385}$ & $\underline{0.462}$ & $\underline{0.758}$
\end{tabular}

Table 2 shows that for each AVE root in each variable is greater than the correlationof each variable, it is said that each variable has fulfilled discriminant validity.

\subsection{Test for Reliability}

Table 3. Composite Reliability - Cronbach's alpha

\begin{tabular}{llcc}
\hline No & \multicolumn{1}{c}{ Variable } & Composite Reliable Cronbach's alpha \\
\hline 1 & X1 (Innovation)) & 0.907 & 0.907 \\
2 & Y1 (Business Competition)) & 0.858 & 0.858 \\
3 & Y2 (Business Development) & 0.844 & 0.844 \\
\hline
\end{tabular}

\subsection{Fit Model Test and Quality Indices}

Table 4. Fit Models and Quality Indices

\begin{tabular}{|c|c|c|c|c|}
\hline No & Model fit - Quality Indices & Fit Criteria & Analisys Result & Remark \\
\hline 1 & Average path Coefficient (APC) & $\mathrm{P}<0.05$ & $\begin{array}{c}0.398 \\
(\mathrm{P}<0.001)\end{array}$ & Good \\
\hline 2 & Average R-squared (ARS) & $\mathrm{P}<0.05$ & $\begin{array}{c}0.312 \\
(\mathrm{P}<0.001)\end{array}$ & Good \\
\hline 3 & Average adjusted R-squared (AARS) & $\mathrm{P}<0.05$ & $\begin{array}{c}0.309 \\
(\mathrm{P}<0.001)\end{array}$ & Good \\
\hline 4 & Average block VIF (AVIF) & Acceptable if $<=5$ Ideally $<=3.3$ & 1.375 & Ideal \\
\hline 5 & Average full collinearity VIF (AFVIF) & Aceecptabel if $<=5$ Ideally $<=3.3$ & 1.676 & Ideal \\
\hline 6 & Tenenhaus GoF (GoF) & $\begin{array}{c}\text { Same }>=0.1 \\
\text { Medium }>=0.25 \\
\text { Large }>=0.36\end{array}$ & 0.435 & Large \\
\hline 7 & Sympson’s Paradox Ratio (SPR) & $\begin{array}{l}\text { Acceptabel if }>=0.7 \\
\text { Ideally }=1\end{array}$ & 1.000 & Ideal \\
\hline 8 & R-squared Contribution Ratio (RSCR) & $\begin{array}{c}\text { Acceptabel if }>=0.7 \\
\text { Ideally }=1\end{array}$ & 1.000 & Ideal \\
\hline 9 & Statistical Supression Ratio & Acceptabel if $>=0.7$ & 1.000 & Ideal \\
\hline 10 & $\begin{array}{l}\text { Nonlinear Bivariate Causality } \\
\text { Direction Ratio (NLBCDR) }\end{array}$ & Acceptabel if $>=0.7$ & 1.000 & Ideal \\
\hline
\end{tabular}




\subsection{Outer Loading Variables}

Table 5. Outer Loading

\begin{tabular}{clcc}
\hline No & Variable & Indikator & Loading Factor \\
\hline 1 & X1 (Innovation)) & X2.2 & 0.844 \\
2 & Y1 (Business Competition)) & Y1.3 & 0.810 \\
3 & Y2 (Business Development) & Y2.3 & 0.795 \\
\hline
\end{tabular}

This study shows the X2.2 is the strongest indicator in the Innovation variable (X1), has the largest loading factor (0.844), for the Y1.3 indicator the strongest is the Business Competition variable (Y1) with the largest loading factor (0.810), Y2.3 is called the strongest indicator for Business Development variable (Y2) where the biggest loading factor is (0.795).

\subsection{Hypothesis testing}

The results of this test have an influence on each variable, and obtained the results of hypothesis testing:

Table 6. Test Results for Hypotheses

\begin{tabular}{cccccc}
\hline No & $\begin{array}{c}\text { Relations between variables } \\
\text { (Explanatory variable -- } \square \text { Response } \\
\text { Variable) }\end{array}$ & Coefficient of Path & p-value & Information \\
\hline 1 & X1 & Y1 & 0.425 & $\mathrm{p}<0.11$ & Highly Sig \\
2 & X2 & Y1 & 0.486 & $\mathrm{p}<0.01$ & Highly Sig \\
3 & Y1 & Y2 & 0.478 & $\mathrm{p}<0.01$ & Highly Sig \\
\hline
\end{tabular}

Hypothesis 1: The written increase in Innovation (X1), will be more influential on business competition (Y1) with a path coefficient of 0.486 with a positive sign and $p<0.01$, where the $p$ value is less than 0.01 , this can be called very significant, then hypothesis 1 is accepted and very significant, meaning that more use a lot of innovation (X2), increasingly giving effect to business competition (Y1). Hypothesis 2; The increasing level of business competition (Y1) has an impact on Business Development (Y2) with a path coefficient of 0.478 which is positive and $\mathrm{p}<0.01$, considering that $\mathrm{p}$ is less than 0.01 , it can be said to be very significant. So that Hypothesis 3 can be accepted and very significant, this means that the higher the business competition (Y1), the more influential business development (Y2) is.

\subsection{Analysis of the Model in the Structural Path}

Research using PLS Wrap analysis, this tool can be used to check on path analysis and used to test the model in the hypothesis. The sample analyzed 365 respondents. The results obtained are shown in Figure 1.

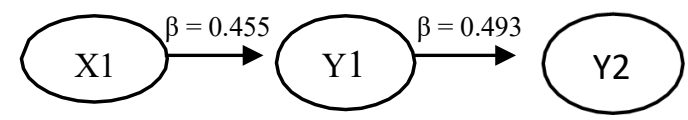

Fig.1. Structural model results 


\subsection{Discussion}

The results of this research test, the strength of innovation has an influence on the level of business competition, the results of this study are in line with the research of Syoum Negassi and Tsu-Yi Hung (2014). In the civil sector, the index has a positive and significant relationship between competition and innovation output. Research by Aleksei Bereznoi, (2015) states that in analyzing innovation in business models, the main competitive instrument in large companies, researchers can explore the concept of a business model by identifying features for innovative business models to be used as a competitive tool in today's volatile market., An explanation of the challenges involved in the approach to implementing innovation. To determine the OSS innovation process, one can see the impact of increased competition on different cost structures for innovative activities in the industry, which has so far been neglected in the literature (Jürgen Bitzer and Philipp J. H. Schröder 2007). Another study using and using a model with duopoly product innovation, was able to show companies which should choose to use research and development arrangements in different cooperatives and this is highly competitive. Behavior at equilibrium, indeed necessary for the relationship between competition and innovation, differently, this depends on the cooperative arrangement in the firm (S.E. Østbye and M.R. Roelofs, 2013).

The results of this test illustrate that the increasing influence of business competition will be able to influence business development, where the results of this study can be in line with other studies which state that having a competitive advantage in a travel agency can be realized well if the company is able to maintain good relations with its competitors and can also adopt a profit orientation, also when implementing a business competition strategy must be right and also the intention of the entrepreneur to offer new services to customers to competitors (CH Liu, AY Chang, JS Horng, SF Chou and YC Huang 2019). Competing authorities can ignore an important aspect of business life: companies can form business relationships. The competition authority evaluates for $\mathrm{M}$ and As based on the risk of price increases, also ignores issues on the heterogeneity of supply, demand, and value built on existing business relationships (Helén Anderson, Johan Holtström and Christina Öberg 2012).

The issue is introduced specifically for the business response to competition policy in Europe which will consider the development of its research in competition policy in Europe. The analysis concentrates on policy developments over time and surprisingly little is known about business responses to competition policy demands (Neil Rollings and Laurent Warlouzet, 2018). Ecopreneurs really need certain business competencies to be successful, especially regarding the ability to translate green values into their business operations and provide their product offerings as well as their business relationships. The most important thing is having competence in the development of products with high added value, because this can reflect a green value and can communicate to customers (Sanna-Mari Renfors, 2019).

\section{Conclusion dan Implication}

This research presents a new perspective on the relationship between 4 Customer variables, Innovation which gives a positive influence on business competition and business development. This research has examined the 4 variables that provide a clear picture in determining business trips. This research will also add confidence to small and medium entrepreneurs in the City of South Tangerang to be more customer-oriented, Innovation which will give effect to businesses that are more competitive and can also be more developed. This research also provides direction 
for South Tangerang city government policy managers in developing small and medium entrepreneurs.

\section{References}

[1] Akhmad Mujahidin (2007). Ekonomi Islam, Jakarta: PT. Raja Grafindo Persada Arief Bowo Prayoga Kasmo et. al (2017) . The Influence Social Media on Buying Intention of MSME's Product (Case Study of Chips Talas Dessy). Prosiding seminar Nasional EkonomiV 2017.

[2] Aleksadra Stoilkovska, Natasha Ristovska and Sashko Gramatnikovski. (2015). "Innovative Business Models a factor for Competitive Anvantage of The Companises." UTMS Journal of Economics 6 (1).

[3] Aleksei Bereznoi. 2015. "Business Model Innovation in Corporate Competitive Strategy." Problems of Economic Transition, Volume 57 (8).

[4] Anoraga, Pandji (2011). Pengantar Bisnis Pengelolaan Bisnis Dalam Era Globalisasi. Jakarta: Rineka Cipta

[5] Anyanitha Distanont and Orapan Khongmalai. (20180. "The role of innovation in creating acompetitive." Kasetsart Journal of Social Sciences, XXX.

[6] Avanti Fontana. (2011). “Innovate We Can!”. Bekasi : Cipta Inovasi Sejahtera

[7] Basu, Swastha (2009). Manajemen Pemasaran. Jakarta: Erlangga.

[8] Chih-Hsing Liu, Angela Ya-ping Chang, Jeou-Shyan Horng, Sheng-Fang Chou and Yung-Chuan Huang (2019). Co competition, learning, and business strategy for new service development." The Service Industries Journal. Published Online (2019).

[9] Dhewanto, Wawan, et.al (2015). Manajemen Inovasi Untuk Usaha Kecil \& Mikro. Bandung : Alfabeta

[10] Dudi Permana (2018). Tourist's Re- visit Intention from Perspective of Value Perception, Destination Image and Satisfaction. European Research Studies Journal, Volume XXI, Issue 3, 2018, pp. 254-265

[11] Hall, James A. dan Singleton, Tommie. (2009). Information Technology Auditing and Assurance. Jakarta: Salemba Empat.

[12] Hammer, Michael and James Champy. Reengineering the Corporation. New York : Harper Business, 1993

[13] Hartono, M Jogiyanto. 2005. Analisa dan Desain Sistem Informasi. Andi Offset Yogyakarta

[14] Hee Sub Byun, Ji Hye Lee \& Kyung Suh Park. 2018. "Product Market Competition and the Ownership Choice of Business Groups: Evidence from Korean Chaebols." Emerging Markets Finance and Trade, Volume 54 (1).

[15] Helén Anderson , Johan Holtström \& Christina Öberg. (20120. "Do Competition Authorities Consider Business Relationships?” Journal of Business-to-Business Marketing, Vol 19 (1).

[16] Jürgen Bitzer and Philipp J. H. Schröder. (2007). "Open Source Software, Competition and Innovation.” Industry \& Innovation, Volume 14 (5)

[17] Magal, S. R., dan Word, J. (2012). Integrated Business Process with ERP Systems. New Jersey: John Wiley \& Sons

[18] Murray D. Rice and Joshua P. Bova. (2020). "Business District Development and Competition: An Exploration of Structural Evolution in the Retail Districts of Denton, Texas." Papers in Applied Geography, Volume 6 (1).

[19] Neil Rollings and Laurent Warlouzet (2018). Business history and European integration: How EEC competititon policy affected companies' strategis. Business History." Published Online: $11 \mathrm{Jul}$ 2018.

[20] Nitisusantro, Mulyadi (2010). Kewirausahaan dan Manajemen Usaha Kecil. Bandung: Alfabeta

[21] Rainer, R Kelly, Cegielski and Casey G. 2011. "Introduction to Information System Enabling and Transformating Business, Third Edition." Canada : John Wiley \& Sons,Inc.

[22] Rusdiana. 2014. "Entrepreneurial Theory and Practice." Bandung: CV Pustaka Setia Sanna Mari 
Renfors. 2019. "Identification of ecopreneurs' business competencies for training program development." Journal of Education for Business, Volume 95(1).

[23] Sonny Indrajaya. 2019. "Culinary Tourism Analysis at Restaurants with Tourism Satisfaction Mediation". European Research Studies Journal, Volume 22 (3).

[24] Stein E. Østbye and Matthew R. Roelofs. (2013). "The competition - innovation debate: is R and D cooperation the answer? Economics of Innovation and New Technology, Volume 22 (2)

[25] Stoilkovska, Aleksandra, Natasha Ristovska, and Sashko Gramatnikovski. (2015). Innovative Business Models aFactor for Competitive Advantage of the Companies. UTMS Journal of Economics 6 (1).

[26] Suraksha Guptaa, Naresh K.Malhotra, Michael Czinkotac and Pantea Foroudi. (2016). "Marketing innovation: A consequence of competitiveness." Journal of Business Research, Volume 69 (12).

[27] Sutarno. (2012). "Everything About Business Management." Yogyakarta : Graha Ilmu.

[28] Syoum Negassi and Tsu-Yi Hung. (2014). "The nature of market competition and innovation: does competition improve innovation output?" Economics of Innovation and New Technology, Volume 23 (1)

[29] Thamrin Abdullah. 2012. “Marketing Management.” Jakarta: Raja wali Press. 